\title{
Atrial enlargement associated with non-valvular atrial fibrillation: an unusual cause of dysphagia and weight loss
}

\author{
Jacob S Heng, ${ }^{1,2}$ Ahmed Elghamaz ${ }^{2}$
}

${ }^{1}$ Imperial College London, London, UK

${ }^{2}$ Department of Cardiology, Northwick Park Hospital, London, UK

Correspondence to Dr Jacob S Heng, jacob.heng@ outlook.com

Accepted 12 February 2015
CrossMark

\section{To cite: Heng JS,}

Elghamaz A. BMJ Case Rep Published online: [please include Day Month Year] doi:10.1136/bcr-2014209213

\section{DESCRIPTION}

A 71-year-old woman presented with a 2 -month history of intermittent solid dysphagia and weight loss of $7 \mathrm{~kg}$. She reported no difficulty with swallowing liquids and also denied any anorexia, vomiting, nausea or change in voice. In addition, she had no change in bowel habit, jaundice or pale stools. Her medical history included paroxysmal atrial fibrillation and non-ischaemic dilated cardiomyopathy of 10-year duration, which was managed using multiple antiarrhythmic medications. She has no history of rheumatic fever. An oesophagogastroduodenoscopy showed pulsatile external compression in the lower oesophagus at $32 \mathrm{~cm}$ from the incisors with normal overlying mucosa (figure 1). CT of the chest confirmed cardiomegaly with left atrial enlargement indenting the adjacent oesophagus (figure 2), with no evidence of thoracic or abdominal aneurysm. The patient's echocardiogram showed biventricular and biatrial enlargement with left ventricular ejection fraction of $10 \%$, but with no evidence of significant mitral stenosis. A barium swallow confirmed indentation of the lower oesophagus by the left atrium, causing a moderate degree of obstruction. The patient was managed on a soft diet including purées and soups, as she was unable to tolerate solid foods. Dysphagia secondary to left atrial enlargement is often seen in Ortner's syndrome ${ }^{1}$ in the context of post-rheumatic mitral stenosis with associated recurrent laryngeal nerve compression. Isolated dysphagia secondary to an

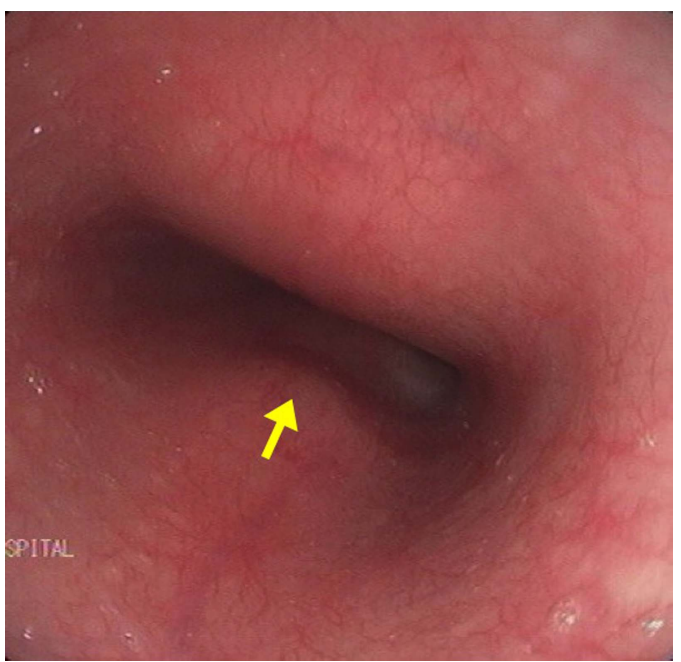

Figure 1 Oesophagogastroduodenoscopy image showing external compression of oesophagus by pulsatile mass (indicated by arrow).

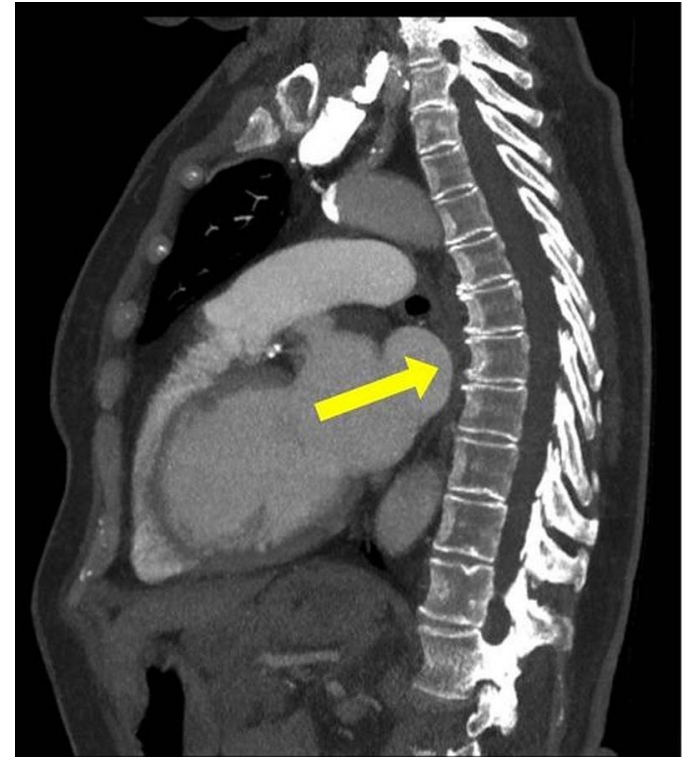

Figure 2 Chest CT showing enlarged left atrium compressing posteriorly (indicated by arrow) on oesophagus.

enlarged left atrium without evidence of recurrent laryngeal nerve palsy, termed 'cardiovascular dysphagia', ${ }^{2}$ can also occur, as in this case, but usually in the context of significant mitral stenosis. ${ }^{2}$

\section{Learning points}

- Left atrial enlargement is an uncommon cause of dysphagia.

- Such dysphagia can be seen with voice hoarseness in Ortner's syndrome or without voice hoarseness in 'cardiovascular dysphagia'.

- Management of dysphagia secondary to atrial enlargement is symptomatic.

Competing interests None.

Patient consent Obtained.

Provenance and peer review Not commissioned; externally peer reviewed.

\section{REFERENCES}

1 Ortner N. Recurrent laryngeal nerve paralysis due to mitral value stenosis. Wien Klin Wochenschr 1897:10:753-5.

2 Cappell MS. Endoscopic, radiographic, and manometric findings associated with cardiovascular dysphagia. Dig Dis Sci 1995;40:166-76 


\section{Images in...}

Copyright 2015 BMJ Publishing Group. All rights reserved. For permission to reuse any of this content visit http://group.bmj.com/group/rights-licensing/permissions.

BMJ Case Report Fellows may re-use this article for personal use and teaching without any further permission.

Become a Fellow of BMJ Case Reports today and you can:

- Submit as many cases as you like

- Enjoy fast sympathetic peer review and rapid publication of accepted articles

- Access all the published articles

- Re-use any of the published material for personal use and teaching without further permission

For information on Institutional Fellowships contact consortiasales@bmjgroup.com

Visit casereports.bmj.com for more articles like this and to become a Fellow 